\title{
Effect of supplementary feeding to ewes and suckling lambs on ewe and lamb live weights while grazing wheat stubble
}

\author{
T.S. Brand ${ }^{1,2 \#} \&$ L. Brundyn ${ }^{2}$ \\ ${ }^{1}$ Directorate: Animal Sciences, Department of Agriculture, Western Cape Government, Private Bag X1, \\ Elsenburg, 7607, South Africa \\ ${ }^{2}$ Department of Animal Sciences, Stellenbosch University, Stellenbosch, South Africa
}

(Received 13 February 2014; Accepted 18 February 2015; First published online 24 March 2015)

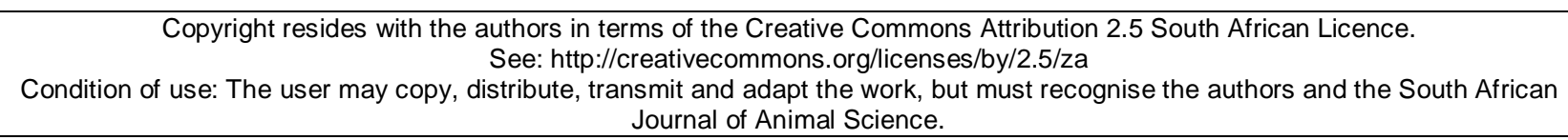

\begin{abstract}
A trial was conducted to determine the effects on the performance of creep feeding suckling lambs and supplementing ewes that were grazing wheat stubble. Eight experimental units of South African Mutton Merino (SAMM) ewes and lambs were used in a 2 (supplementing ewes or not) $\times 2$ (creep feeding lambs or not) factorial design. Two groups, consisting of 68 and 100 ewes, grazed 12.9 ha and 18 ha paddocks, respectively. Each group was then divided into four sub-groups, of which two sub-groups received supplementation and two were not supplemented. Within each ewe group, two groups of lambs received creep feeding and two groups did not. Ewe groups were rotated between these camps each week to eliminate the effect of camps. Supplementation at $200 \mathrm{~g} /$ day took place from February 2000 to May 2000, after which it was increased to $300 \mathrm{~g} /$ day until August 2000. The liveweight change (LWC) of ewes during the total experimental period from 22 November to 31 August, as well as during the feeding period from 22 February to 31 August, was not affected significantly by supplementation, although ewes that received supplementary feed maintained higher live weights for a large part of the experimental period. The average daily gain (ADG) of lambs from ewes that received supplementary feed tended $(9 \%)$ to be higher compared to the lambs of ewes that did not received any supplementary feed. There was no significant difference in the LWC of ewes during the total experimental period or during the feeding period due to the creep feeding of their lambs. The ADG of the lambs that received creep feeding from 24 May to 28 August was $25 \%$ higher than that of lambs that did not receive it, and the creep-fed lambs maintained higher live weights for most of the experimental period.
\end{abstract}

\footnotetext{
Keywords: Creep feeding, SA Mutton Merino ewes, supplementation, wheat stubble

\# Corresponding author: tersb@elsenburg.com
}

\section{Introduction}

The Swartland, situated in the winter rainfall region of South Africa, is a cereal-growing area in which many farms produce autumn lambs. Pregnant and lactating ewes are dependent on crop residues in summer and early autumn until the first rains fall. Cereal stubble refers to plant material that is available on the land after harvesting the grain, with green herbage from weed seeds and spilt grain that germinate after rain (Dann \& Coombe, 1987). Wheat stubble is characterized by low levels of nitrogen and carbohydrates, poor digestibility and high cell-wall content (Dann \& Coombe, 1987). It does not supply sufficient nutrients to fulfil the high protein and energy needs of reproducing ewes (Aitchison, 1988; Brand et al., 2000). Owing to the low digestibility of wheat stubble, there is reduced intake (Mulholland et al., 1976), which results in a decrease in the nutrient intake by ewes. Supplementary feeding is needed for additional energy and protein (Aitchison, 1988; Brand et al., 1997a).

Creep feeding is the practice of providing nursing lambs with an opportunity to eat high-quality feed other than dams' milk and forage. The provision of creep feeding may be economically viable in twin or triplet suckled lambs when pastures decline in quality and quantity or when the growth potential of lambs is not being met with milk and natural forage. Early exposure to grain diets also improves acceptance of these feeds later in life (Thorhallsdottir et al., 1990). There is a dearth of scientific information about the efficiency of creep feeding for lambs grazing wheat stubble.

This study evaluated the effects of creep feeding suckling lambs and supplementing their dams on the performances of ewes and lambs that are grazing wheat stubble. 


\section{Materials and Methods}

The experiment was conducted at Langgewens Research Farm $\left(33^{\circ} 17^{\prime} \mathrm{S}, 18^{\circ} 42^{\prime} \mathrm{E}\right.$, altitude $\left.177 \mathrm{~m}\right)$, in the Swartland area of the winter rainfall region of South Africa. The area receives $78 \%$ of the average annual precipitation of $395 \mathrm{~mm}$ in winter, and has a Mediterranean climate. A total of 168 South African Mutton Merino (SAMM) ewes was chosen at random and synchronized with Repromap ${ }^{\circledR}$ (medroxyprogesterone acetate, $60 \mathrm{mg}$ ) sponges and mated from 18 November 1999 with ca. 3\% rams. One group of 100 ewes was divided into four groups, which grazed an 18 ha wheat stubble paddock at a stocking density of 5.5 ewes/ha. The remaining 68 ewes were divided into four groups, and grazed a 12.9 ha wheat stubble camp at a stocking density of 5.3 ewes/ha. To eliminate the effects of camps, sheep were rotated between them. Each group was subdivided into four groups, of which two groups of lambs received creep feed and two groups received none. Similarly, two groups of ewes received supplementary feed and two received none.

The experiment was performed under a 2 (supplementing ewes or not) $\times 2$ (creep feeding lambs or not) factorial design. Supplementation for these ewe groups, supplied at $200 \mathrm{~g} / \mathrm{d}$, took place from 22 February 2000 to 2 May 2000 (69 days), after which it was increased to $300 \mathrm{~g} / \mathrm{d}$ from 3 May 2000 until 31 August 2000 (120 days) (Table 1). Supplementation was supplied as a loose feed mix meal with a high concentration of salt (feed lick) to restrict intake and ensure a constant feed intake over a long period of time (Table 2).

Table 1 Experimental details of SA Mutton Merino ewes supplemented or not supplemented while grazing wheat stubble

\begin{tabular}{|c|c|c|}
\hline \multirow{2}{*}{ Experimental details } & \multicolumn{2}{|c|}{ Experiment number } \\
\hline & 1 & 2 \\
\hline Year & $1999 / 2000$ & $1999 / 2000$ \\
\hline Type of stubble & Wheat & Wheat \\
\hline Paddock size (ha) & 18 & 12.9 \\
\hline Number of ewes & 100 & 68 \\
\hline Number of groups & 4 & 4 \\
\hline Stocking density & 5.5 & 5.3 \\
\hline \multicolumn{3}{|l|}{ Stubble grazing: } \\
\hline Starting date & 22 Nov. 1999 & 22 Nov. 1999 \\
\hline End date & 31 Aug. 2000 & 31 Aug. 2000 \\
\hline Number of days & 282 & 282 \\
\hline \multicolumn{3}{|c|}{ Supplementation of ewes ${ }^{A}$} \\
\hline Starting date & 22 Feb. 2000 & 22 Feb. 2000 \\
\hline End date & 31 Aug. 2000 & 31 Aug. 2000 \\
\hline Number of days & 190 & 190 \\
\hline \multicolumn{3}{|l|}{ Creep feeding of lambs } \\
\hline Starting date & 24 May 2000 & 24 May 2000 \\
\hline End date & 28 Aug. 2000 & 28 Aug. 2000 \\
\hline Number of days & 96 & 96 \\
\hline \multicolumn{3}{|l|}{ Amount $^{A}$} \\
\hline 69 days & $200 \mathrm{~g} / \mathrm{d}^{+}$ & $200 \mathrm{~g} / \mathrm{d}^{+}$ \\
\hline 120 days & $300 \mathrm{~g} / \mathrm{d}^{++}$ & $300 \mathrm{~g} / \mathrm{d}^{++}$ \\
\hline
\end{tabular}


Creep feeding for lambs consisted of the same ingredients as the ewe supplement and was supplied ad libitum to lambs from 24 May 2000 until 28 August 2000 (96 days). Lambs consumed an average of 0.58 $\mathrm{kg}$ creep feed/lamb/day.

Table 2 Physical and chemical composition of the supplementary feed mix (lick) supplied to producing SA Mutton Merino ewes and creep feed for suckling lambs grazing wheat stubble during the dry summer period

\begin{tabular}{lc}
\hline Item & Content \\
\hline Physical composition (air dry) (\%) & \\
Barley meal & 57.0 \\
Cottonseed oil-cake meal & 22.1 \\
Urea & 3.7 \\
Feed lime & 1.55 \\
Molasses meal & 1.5 \\
Sulphur & 0.15 \\
Salt & 14.0 \\
Chemical composition (dry matter) (g/kg) & \\
Dry matter & 855 \\
Crude protein & 174 \\
Crude fibre & 67 \\
Ether extract & 22 \\
Ash & 48 \\
Total digestible nutrients & 637 \\
Metabolisable energy (MJ/kg) & 9.6 \\
Calcium & 6 \\
Phosphorus & 4 \\
Magnesium & 3 \\
Sulphur & 3 \\
\hline
\end{tabular}

All treatment means were compared with the least significant difference (LSD) method. In line with recommendations by Snedecor \& Cochran (1980), the LSD test was used only when it was protected by a significant F-value in the analysis of variance table. The initial live weights of ewes were used as a covariant in analysis of the ewe data. Ewe and lamb data were corrected for multiple births by linear model procedures. Data were analysed with Statgraphics Centurion Version XV (StatPoint, 2005).

\section{Results and Discussion}

Liveweight change (LWC) of ewes receiving supplementation or none and ewes whose lambs received creep feeding or none, are presented in Tables 3 and 4 . The results show that LWC of ewes either during the total experimental $(P=0.11)$ period or during the feeding period $(P=0.24)$ was not affected by the provision of supplementary feed to them. Table 4 also shows no difference in the LWC of ewes during the entire experimental period $(P=0.57)$ or the feeding period $(P=0.66)$ when their lambs received creep feeding or none.

The average daily gain $(A D G)$ of lambs that received creep feeding was $25 \%$ higher $(P<0.001)$ than lambs that received none (Table 4). The ADG of lambs tended $(P=0.07)$ to be $9 \%$ higher in lambs whose mothers received supplementation than in those whose mothers received none (Table 3). Similarly, Terblanche et al. (2012) found $28.5 \%$ increase in the LWC of lambs supplied with creep feed whose dams grazed medic pasture and $81.6 \%$ increase in the LWC of lambs that were supplied with creep feed whose dams grazed kikuyu pasture. No effects of the provision of creep feed to lambs on ewe LWC were obtained on medic pasture, while ewe live weight on kikuyu pasture increased significantly when their lambs received 
creep feed (Terblanche et al., 2012). This accentuates the role of the quality of the pasture when providing supplementary feed to sheep.

Table 3 Influence of supplementation on mean live weights of SA Mutton Merino ewes and their lambs when grazing wheat stubble

\begin{tabular}{|c|c|c|c|c|}
\hline \multirow{2}{*}{ Parameter } & \multicolumn{2}{|c|}{ Treatment } & \multirow{2}{*}{ SEM } & \multirow{2}{*}{$P$} \\
\hline & Supplementation & No supplementation & & \\
\hline \multicolumn{5}{|l|}{ Ewes } \\
\hline Initial bodyweight (kg) & 71.0 & 71.0 & 0.85 & 0.35 \\
\hline Final bodyweight $(\mathrm{kg})$ & 63.6 & 60.7 & 1.40 & 0.11 \\
\hline $\begin{array}{l}\text { Weight change, total experimental } \\
\text { period }(\mathrm{kg})\end{array}$ & -7.5 & -10.4 & 1.40 & 0.11 \\
\hline Weight change, feeding period $(\mathrm{kg})$ & -7.2 & -9.6 & 1.50 & 0.24 \\
\hline \multicolumn{5}{|l|}{ Lambs } \\
\hline Initial bodyweight $(\mathrm{kg})$ & 4.50 & 4.50 & 0.10 & 0.97 \\
\hline Final bodyweight (kg) & 34.6 & 32.4 & 0.87 & 0.07 \\
\hline Average daily gain (kg/day) & 0.24 & 0.22 & 0.006 & 0.06 \\
\hline
\end{tabular}

Table 4 Influence of creep feeding of lambs on the mean live weights of SA Mutton Merino ewes and their lambs when grazing wheat stubble

\begin{tabular}{|c|c|c|c|c|}
\hline \multirow{2}{*}{ Parameter } & \multicolumn{2}{|c|}{ Treatment } & \multirow{2}{*}{ SEM } & \multirow{2}{*}{$P$} \\
\hline & Creep feeding & No creep feeding & & \\
\hline \multicolumn{5}{|l|}{ Ewes } \\
\hline Initial bodyweight (kg) & 71.0 & 71.0 & 0.85 & 0.46 \\
\hline Final bodyweight $(\mathrm{kg})$ & 62.7 & 61.6 & 1.40 & 0.57 \\
\hline $\begin{array}{l}\text { Weight change, total experimental period } \\
(\mathrm{kg})\end{array}$ & -8.4 & -9.5 & 1.40 & 0.57 \\
\hline Weight change, feeding period (kg) & -7.9 & -8.8 & 1.5 & 0.66 \\
\hline \multicolumn{5}{|l|}{ Lambs } \\
\hline Initial bodyweight (kg) & 4.5 & 4.5 & 0.10 & 0.03 \\
\hline Final bodyweight $(\mathrm{kg})$ & $36.5^{\mathrm{a}}$ & $30.6^{\mathrm{b}}$ & 0.93 & 0.001 \\
\hline Average daily gain (kg/day) & $0.25^{\mathrm{a}}$ & $0.20^{\mathrm{b}}$ & 0.007 & 0.001 \\
\hline
\end{tabular}

Values in rows followed by the same letter have no significant effect at $P=0.05$.

Figure 1 illustrates the LWC of ewes that received supplementation in contrast to those that received none (total experimental period). Ewes receiving supplementation showed a significant difference in live weight $(P<0.01)$ from day 85 to day 225 of feeding (Figure 1). No difference was observed in the LWC of the ewes whose lambs received creep feeding (Figure 2). The results indicate that the direct supplementation of ewes during lactation resulted in their maintaining a higher live mass for most of the time, which may be beneficial for future production and reproduction (Gunn, 1983). Supplementation to lambs did not affect ewe live weight in this study.

Figures 3 and 4 illustrate the LWG of lambs as affected by supplementation of their dams and by creep feeding. 


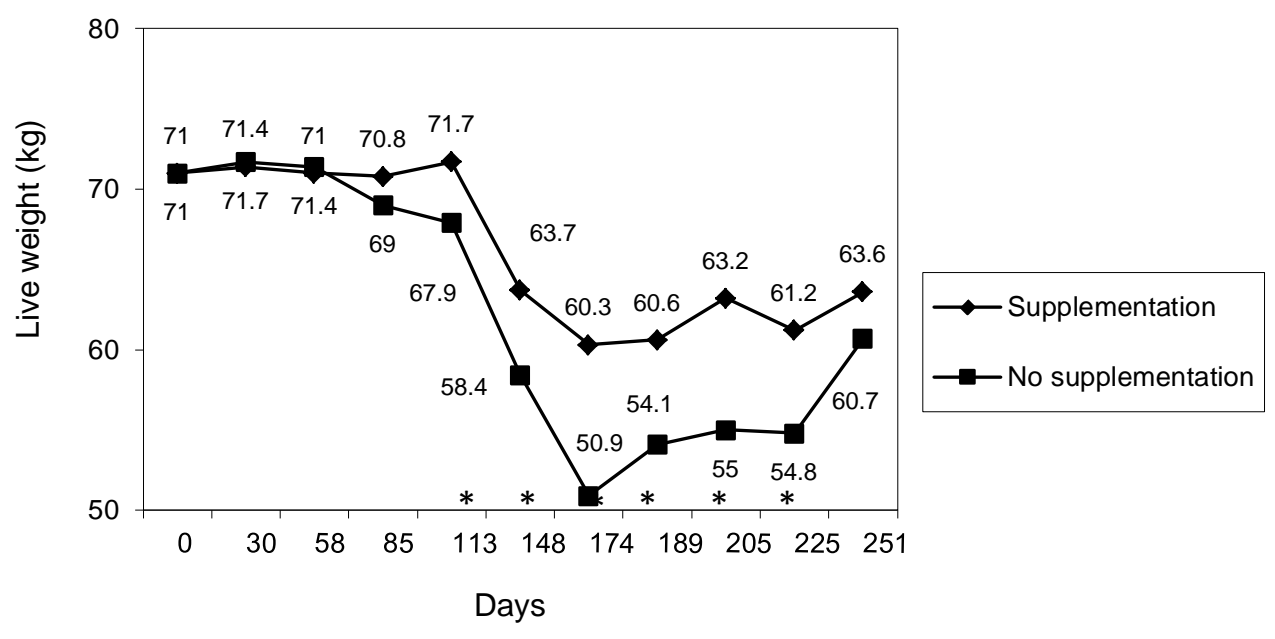

*Denotes a significant difference $(P<0.01)$

Figure 1 Liveweight change of SA Mutton Merino ewes grazing wheat stubble and receiving supplementation or not (total experimental period.

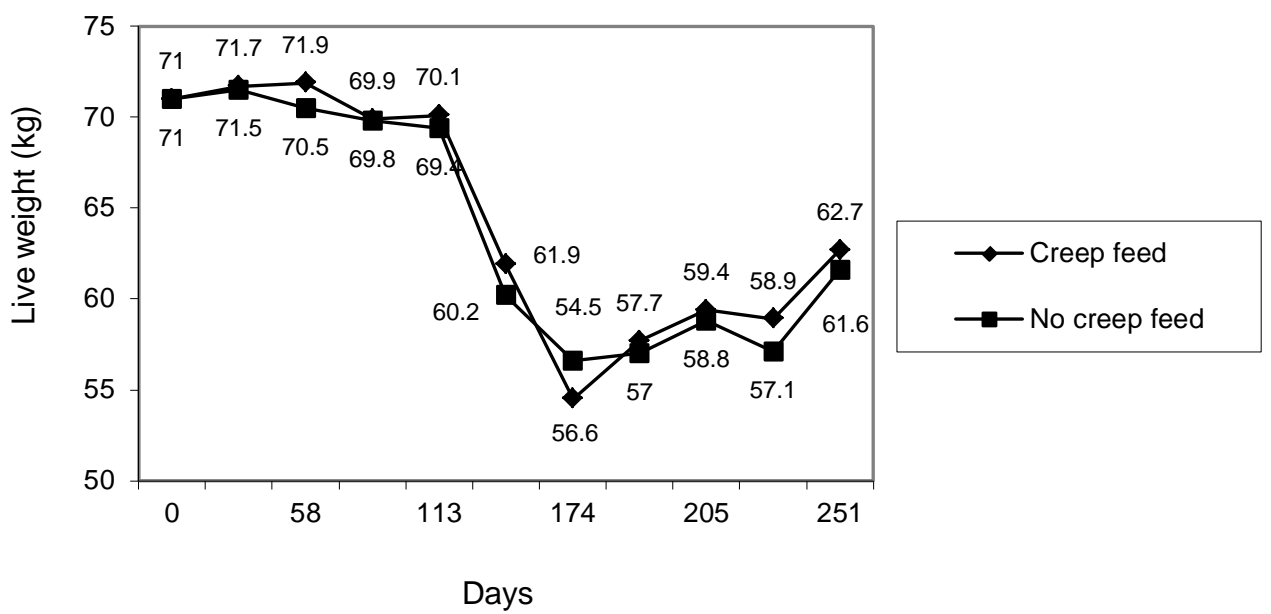

Figure 2 Liveweight change of SA Mutton Merino ewes grazing wheat stubble with lambs that received creep feeding or not (total experimental period).

Supplementation of ewes affected the LWG of lambs positively $(P<0.03)$ between days 40 and 91 (Figure 3) and creep feeding affected the LWG of lambs positively $(P<0.01)$ between days 55 and 125 of the experiment (Figure 4). These results differ from those obtained by Thomas \& Kott (1989), who found that creep feeding had no effect on lamb gains from birth to turnout on summer pasture. In their experiment creep-fed lambs gained $7.60 \mathrm{~kg}$ compared with $6.90 \mathrm{~kg}$ for non-creep-fed lambs. During the pasture phase of their experiment, the creep-fed group of lambs gained more weight $(P<0.001)$ than those that were not creep fed during the experimental period (Thomas \& Kott, 1989). 


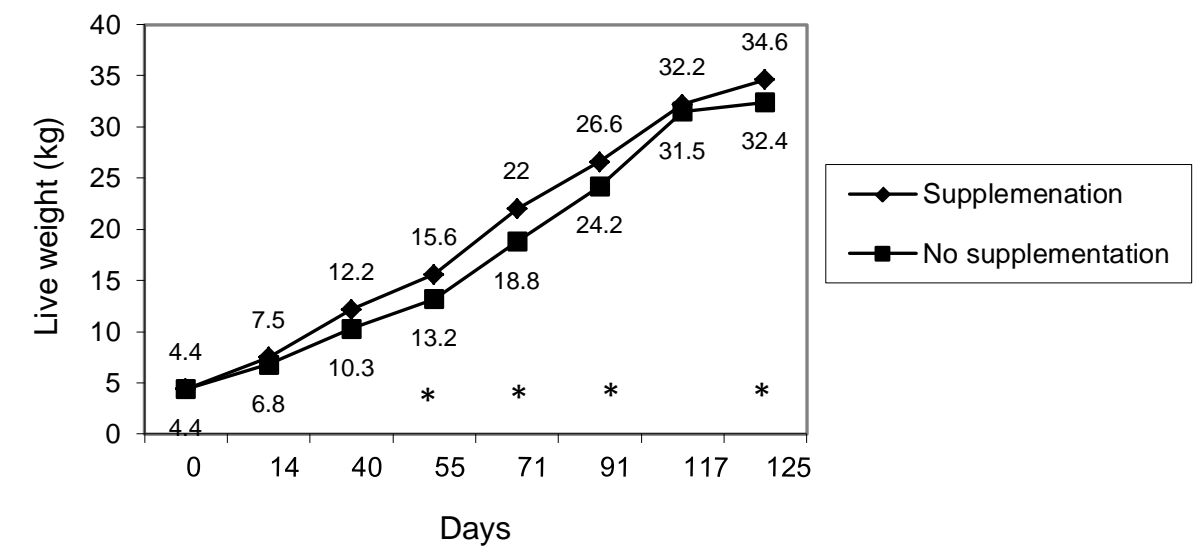

* Denotes a significant difference $(P<0.03)$

Figure 3 Liveweight change of SA Mutton Merino lambs with mothers that received supplementation or not.

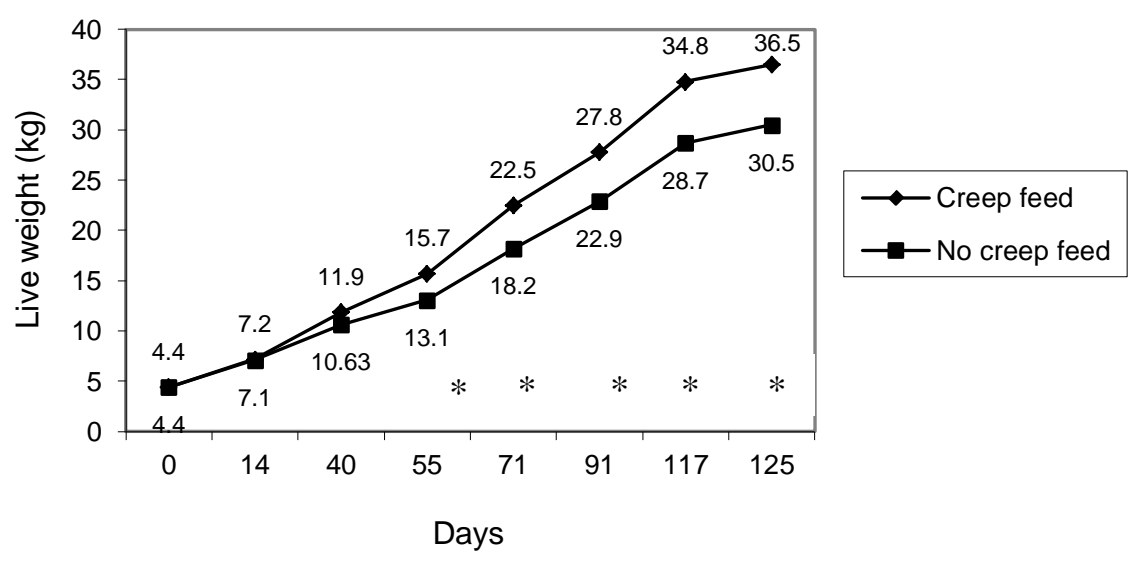

* Denotes a significant difference $(P<0.05)$

Figure 4 Liveweight change of SA Mutton Merino lambs that received creep feeding or not.

In a study by Thorhallsdottir et al. (1990), lambs that were exposed to rolled barley while their mothers were present, consumed more feed than those without their mothers. Lambs probably learn to eat unfamiliar foods better when participating with social models such as their mothers. It may be difficult for young lambs

\section{Conclusion}

Supplementation tended to decrease the liveweight loss of ewes. Consequently supplemented ewes maintained higher body weights during most of the supplementary period. Supplemented ewes also tended to produce lambs that were $6.8 \%(P<0.07)$ heavier at 125 days old. This may be ascribed to higher milk production because of supplementary feeding. Supplementing ewes is important to reproduction in the following year because of a possible carry-over effect (Gunn, 1983). Creep feeding lambs improved their ADG $(P<0.001)$ by $25 \%$, but did not affect the body weight of their dams. The study indicates that the highest direct advantage, in terms of lamb growth, from providing supplementary feed to sheep that are grazing wheat stubble lands would be from supplying creep feed to the lambs. According to the literature, the provision of creep feed may also be beneficial to lambs that will be placed in feedlots. A study by OrtegaReyes et al. (1992) reported that lambs that are exposed with their mothers to supplementary feed for eight days at six to eight weeks old had higher feed intake for the first two weeks in the feedlot than lambs that 
were not exposed to it. In addition, lambs that are exposed to supplementary feed reached slaughter condition at an earlier age. According to the literature, the quantity and quality of the pasture may also play an important role in the results from providing supplementary feed to ewes and creep feed to lambs (Terblanche et al., 2012).

\section{Acknowledgments}

The technical staff at Langgewens Research Farm, Western Cape Department of Agriculture, is acknowledged for their technical contributions.

\section{References}

Aitchison, E., 1988. Cereal straw and stubble as sheep feed. J. Agric. Western Aust. 29, 96-101.

Brand, T.S., 1996. The nutritional status and feeding practices of sheep grazing cultivated pasture and crop residues in a Mediterranean environment. Ph.D. Agric thesis. University of Stellenbosch, South Africa.

Brand, T.S., Franck, F., Durand, A. \& Coetzee, J., 1997. Use of varying combinations of energy and protein sources as supplementary feed for lambing ewes grazing cereal stubble. Aust. J. Exper. Agric. 37, $1-9$.

Brand, T.S., Franck, F., Durand, A. \& Coetzee, J., 2000. The intake and nutritional status of sheep grazing wheat stubble. Small Rumin. Res. 35, 29-38.

Dann, P.R. \& Coombe, J.B., 1987. Utilization of fodder crops and crop residues. In: Temperate Pastures, Their Production, Use and Management. Eds: Wheeler, L.W., Pearson, C.G. \& Robards, G.E., Australian Wool Corporation, Australia. pp. 517-525.

Gunn, R.R., 1983. The influence of nutrition on the reproductive performance of ewes. In: Sheep production. Ed: Haresign, W., Butterworths, London. pp. 99-110.

Mulholland, J.G., Coombe, J.B., Freer, M. \& McManus, W.R., 1976. An evaluation of cereal stubbles for sheep production. Aust. J. Agric. Res. 27, 881-893.

Ortega-Reyes, L., Provenza, F.D., Parker, C.F. \& Hatfield, P.G., 1992. Drylot performance and ruminal papillae development of lambs exposed to a high concentrate diet while nursing. Small Rumin. Res. 7, 101-112.

Snedecor, G.W. \& Cochran, W.G., 1980. Statistical Methods. (7th ed.). Iowa State University Press, Ames, lowa. pp. 593.

Statpoint Inc, 2005. Statgraphics Centurion XV User Manuel. www.statgraphics.com.

Terblanche, S., Brand, T.S, Jordaan, J.W. \& Van der Walt, J.C., 2012. Production response of lambs receiving creep feed while grazing two pastures. S. Afr. J. Anim. Sci. 42, 535-539.

Thomas, V.M. \& Kott, R.E., 1989. Influence of creep feeding on lamb performance during a drought. Sheep Res. J. 5, 1-4.

Thorhallsdottir, A.G., Provenza, F.D. \& Balph, D.F., 1990. Ability of lambs to learn about novel foods while observing or participating with social models. Appl. Anim. Behav. Sci. 25, 25. 